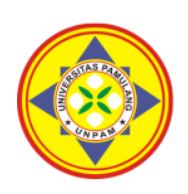

\title{
PENGARUH DISIPLIN KERJA DAN KOMPENSASI TERHADAP KINERJA KARYAWAN RUBBER PROCESS PADA PT TABAD INDUSTRI KOTA TANGERANG SELATAN
}

\author{
1Puadi Purbawi, ${ }^{2 *}$ Didi Sunardi \\ Universitas Pamulang, Tangerang Selatan, Banten, Indonesia \\ 2*dosen00724@unpam.ac.id
}

\begin{abstract}
Abstrak
Penelitian ini bertujuan untuk mengetahui pengaruh disiplin kerja dan kompensasi terhadap kinerja karyawan rubber process pada PT. Tabad Industri Kota Tangerang Selatan. Metode penelitian ini menggunakan metode asosiatif kuantitatif dengan jumlah responden sebanyak 87 orang. Hasil uji penelitian ini dapat di lihat pada uji analisis regresi linier berganda yang di peroleh persamaan $\mathrm{Y}=$ $7,681+0,351 X_{1}+0,401 X_{2}$. Pada uji koefisien korelasi menunjukkan nilai $R$ sebesar $(0,548)$. Hal ini menunjukkan bahwa korelasi atau hubungan antara kinerja karyawan dengan disiplin kerja dan kompensasi mempunyai tingkat hubungan yang sangat kuat. Pada uji koefisien determinasi (KD) diketahui bahwa R square adalah $30 \%$. Hal ini menunjukkan bahwa persentase pengaruh disiplin kerja dan kompensasi $(\mathrm{X})$ terhadap kinerja karyawan $(\mathrm{Y})$ sebesar 30\%, sedangkan $70 \%$ dipengaruhi atau dijelaskan oleh variabel lain di luar variabel yang di teliti. Berdasarkan hasil Uji $\mathrm{F}$ antara variabel disiplin kerja dan kompensasi terhadap kinerja karyawan diperokeh hasil $\mathrm{F}$ hitung lebih besar dari $\mathrm{F}$ tabel yaitu 25,114 $>3,11$ dengan taraf signifikan 0,000 < 0,050, artinya disiplin kerja dan kompensasi secara simultan mempunyai pengaruh yang positif dan signifikan terhadap kinerja karyawan.
\end{abstract}

Kata Kunci: Disiplin Kerja, Kompensasi, Kinerja Karyawan

\section{Abstract}

This study aims to determine the effect of work discipline and compensation on the performance of rubber process employees at PT. Tabad Industry, South Tangerang City. This research method uses quantitative associative method with the number of respondents as many as 87 people. The test results of this study can be seen in the multiple linear regression analysis test which obtained the equation $Y=7.681+0.351 \mathrm{X} 1+0.401 \mathrm{X}_{2}$. The correlation coefficient test shows an $R$ value of (0.548). This shows that the correlation or relationship between employee performance with work discipline and compensation has a very strong level of relationship. In the coefficient of determination test (KD) it is known that $R$ square is $30 \%$. This shows that the percentage of the influence of work discipline and compensation (X) on employee performance $(Y)$ is $30 \%$, while $70 \%$ is influenced or explained by other variables outside the variables studied. Based on the results of the F test between the variables of work discipline and compensation on employee performance, the calculated $F$ results are greater than $F$ table, namely $25.114>3.11$ with a significant level of $0.000<0.050$, meaning that work discipline and compensation simultaneously have a positive and significant effect on performance. employee.

Keywords: Work Discipline, Compensation, Employee Performance

\section{PENDAHULUAN}

(SDM) memiliki kewajiban untuk membangun perilaku kondusif karyawan. Selain itu, manajemen SDM juga memiliki tugas untuk menciptakan kinerja terbaik bagi perusahaan dan karyawan. Manajemen sumber daya manusia memberikan pengakuan tentang pentingnya tenaga kerja organisasi sebagai sumber daya manusia utama yang memberi kontribusi bagi pencapaian tujuan-tujuan organisasi serta memberikan kepastian bahwa pelaksanaan fungsi dan kegiatan organisasi dilaksanakan secara efektif dan adil bagi kepentingan individu, organisasi dan masyarakat. Oleh sebab itu sumber daya manusia harus di kelola sedemikian rupa sehingga berdaya guna dan berhasil guna dalam mencapai misi dan tujuan organisasi. 
Terdapat hubungan yang erat antara kinerja perseorangan dengan kinerja organisasi. Dengan kata lain bila kinerja karyawan baik maka kemungkinan besar kinerja organisasi juga baik. Oleh karena itu organisasi harus benar-benar memperhatikan faktor sumber daya manusianya.

Salah satu hal yang terpenting dalam tugas manajemen sumber daya manusia adalah untuk menciptakan disiplin kerja. Disiplin kerja memang dibutuhkan untuk suatu perusahaan dalam kaitannya untuk mempermudah dan melancarkan perusahaan dalam mencapai tujuannya.

\section{TINJAUAN PUSTAKA}

a. Manajemen Sumber daya Manusia

Menurut Mangkunegara (2013:2) "manajemen sumber daya manusia merupakan suatu perencanaan, pengorganisasian, pengkoordinasian, pelaksanaan dan pengawasan terhadap pengadaan, pengembangan, pemberian balas jasa, pengintegrasian, pemeliharaan, dan pemisahan tenaga kerja dalam rangka mencapai tujuan organisasi."

Menurut Badriyah (2015:13) "manajemen sumber daya mnusia merupakan bagian dari ilmu manajemen yang memfokuskan perhatiannya pada pengaturan peranan sumber daya manusia dalam kegiatan organisasi."

Sedangkan menurut Mathis dan Jackson dalam Endang Sumaeni (2017:26) "manajemen sumber daya manusia adalah merancang sistem manajemen untuk memastikan bahwa bakat manusia digunakan secara efektif dan efisien untuk mencapai tujuan organisasi."

Berdasarkan keterangan tersebut, dapat disimpulkan bahwa manajemen sumber daya manusia merupakan kegiatan yang berfungsi untuk mengatur, mengolah, serta memanfaatkan sumber daya manusia, dengan harapan tujuan perusahaan dapat tercapai. Perusahaan tidak lagi memandang sumber daya manusia sebagai beban, akan tetapi sebagai aset dalam persaingan dengan perusahaan lain

b. Kompensasi

Tak dapat dipungkiri, upah merupakan salah satu faktor paling krusial dalam upaya meningkatkan motivasi kerja karyawan. Selain gaji pokok dan tunjangan tetap, HRD harus kreatif dalam merancang paket benefit agar kinerja karyawan tetap terjaga, seperti memberikan bonus dan insentif kepada karyawan maupun tim kerja yang telah mencapai target perusahaan

c. Kinerja Karyawan

Kinerja (performance) adalah hasil pekerjaan yang di capai seseorang berdasarkan persyaratan-persyaratan pekerjaan (job requirement). Suatu pekerjaan mempunyai persyaratan tertentu untuk dapat dilakukan dalam mencapai tujuan yang disebut juga sebagai standar pekerjaan ( job standard).

Menurut Sutrisno

"kinerja adalah hasil kerja karyawan di lihat dari aspek kualitas, kuantitas, waktu kerja dan kerja sama untuk mencapai tujuan yang telah ditetapkan oleh organisasi."

Faktor yang mempengaruhi Kinerja Karyawan, adalah sebagai berikut;

1. Ketersediaan Peralatan dan Barang

2. Lingkungan Kerja

3. Job Description dan Tanggung Jawab

4. Visi, Misi dan Budaya Organisasi

\section{METODE}

Penelitian ini merupakan penelitian asosiatif kausal dengan menggunakan pendekatan kuantitatif. Menggunakan pendekatan kuantitatif karena data yang digunakan untuk menganalisis hubungan antar variabel dinyatakan dengan angka atau skala numeric.

Metode yang digunakan dalam penelitian ini menggunakan analisis regresi linier sederhana, dan berganda, analisis koefisien korelasi, analisis determinasi, analisis hipotesis menggunakan uji t dan uji f. Penelitian ini menganalisis pengaruh disiplin kerja dan kompensasi terhadap 
kinerja karyawan

HASIL DAN PEMBAHASAN

Uji Analisis Regresi Linier Sederhana

Uji analisis regresi linier sederhana, digunakan untuk melihat bagaimana

Tabel 1. Hasil Uji Analisis Regresi Linier Sederhana Disiplin Kerja Terhadap Kinerja Karyawan

\begin{tabular}{|c|c|c|c|c|c|}
\hline \multicolumn{6}{|c|}{$1.18 " 1.18^{\prime \prime}$} \\
\hline \multirow{2}{*}{$1.18^{\prime \prime}$} & \multicolumn{3}{|c|}{ Unstandardized Coefficients Standardized Coefficients } & \multirow{2}{*}{$\mathrm{t}$} & \multirow{2}{*}{ Sig. } \\
\hline & $\mathrm{B}$ & Std. Error & Beta & & \\
\hline 1.18" (Constant) & 7,681 & 3,367 & & 2,282 & 024 \\
\hline Disiplin Kerja & ,351 & 116 & 285 & 3,031 & 003 \\
\hline
\end{tabular}

Sumber: Data diolah dari SPSS versi 23 (2021)

Berdasarkan table di atas hasil yang telah di peroleh dari koefisien regresi di atas, maka dapat dibuat suatu persamaan regresi sebagai berikut: $Y=7,681+0,351 X$

Tabel 2. Hasil Uji Analisis Regresi Linier Sederhana Kompensasi Terhadap Kinerja Karyawan

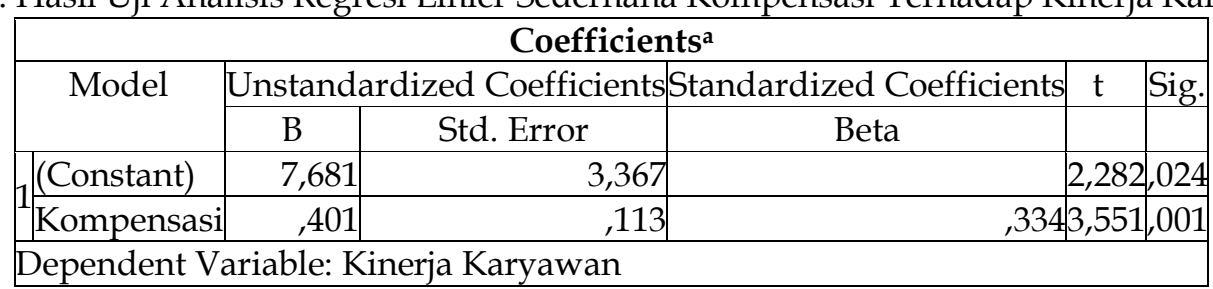

Sumber: Data diolah dari SPSS versi 23

Berdasarkan tabel di atas hasil yang telah di peroleh dari koefisien regresi diatas, model tersebut dapat di interpretasikan sebagai berikut:

a. Nilai konstanta sebesar 7,681 artinya apabila variabel independennya sama dengan nol, maka variabel kinerja karyawan bernilai sebesar 7,681.

b. Nilai koefisien disiplin kerja sebesar 0,401 dapat diartikan bahwa setiap penambahan 1 satuan, maka kompensasi akan naik sebesar 0,401 jika variabel lain tetap. Uji Analisis Regresi Linier Berganda

3. Uji Analisis Regresi Linier Berganda Analisis regresi berganda adalah

Tabel 3. Hasil Uji Analisis Regresi Berganda

\begin{tabular}{|c|c|c|c|c|c|}
\hline \multicolumn{6}{|c|}{$\begin{array}{c}\text { Coefficients }^{a} \\
\end{array}$} \\
\hline \multirow[t]{2}{*}{ Model } & \multicolumn{3}{|c|}{ Unstandardized CoefficientsStandardized Coefficients } & \multirow[t]{2}{*}{$t$} & \multirow{2}{*}{ Sig. } \\
\hline & B & Std. Error & Beta & & \\
\hline (Constant) & 7,681 & 3,367 & & 2,28 & 2,024 \\
\hline 1 Disiplin Kerja & ,351 & ,116 & 285 & 3,03 & 1,003 \\
\hline Kompensasi & 401 & ,113 & ,334 & 3,55 & 1,001 \\
\hline Dependent Var & riable: Kir & Karyawan & & & \\
\hline
\end{tabular}

hubungan secara linier antara dua atau lebih variabel independen (X1 dan X2) dengan variabel dependen $(\mathrm{Y})$. Analisis ini untuk mengetahui arah hubungan antara variabel dependen apakah masing-masing variabel independen berhubungan posistif atau negatif dan untuk memprediksi nilai dari variabel dependen apabila nilai independen mengalami kenaikan atau penurunan. Data yang digunakan

biasanya berskala interval atau rasio. Untuk mengetahui ada tidaknya pengaruh antara dua variabel independen terhadap variabel dependen dapat di lihat dalam tabel berikut: 
Berdasarkan table di atas hasil yang telah di peroleh dari koefisien regresi diatas, maka dapat dibuat suatu persamaan regresi sebagai berikut : $\mathrm{Y}=$ $7,681+0,351$ X1 + 0,401 X2

4. Koefisien Korelasi (R)

Analisis korelasi digunakan untuk mencari hubungan antara dua variabel bebas atau lebih secara bersama sama dihubungkan dengan variabel terikatnya. Sehingga dapat diketahui besarnya sumbangan seluruh variabel bebas yang menjadi objek penelitian variabel terikatnya.

Tabel 4. Hasil Uji Koefisien Korelasi

\begin{tabular}{|c|c|c|c|}
\hline \multicolumn{4}{|c|}{ Model Summaryb } \\
\hline Model R & R Square & Adjusted R SquareStd. Error of the Estimate| & Durbin-Watson \\
\hline \begin{tabular}{|l|l|}
1 &, $548^{\mathrm{a}}$ \\
\end{tabular} & 300 & 2,288 & 2,280 \\
\hline \multicolumn{4}{|c|}{ a. Predictors: (Constant), Kompensasi, Disiplin Kerja } \\
\hline \multicolumn{4}{|c|}{ b. Dependent Variable: Kinerja Karyawan } \\
\hline
\end{tabular}

Sumber: Data diolah dari SPSS versi 23

Pada tabel di atas dapat dilihat dari uji koefisien korelasi dengan menunjukan nilai $\mathrm{R}$ sebesar 0,548 . Hal ini menunjukan bahwa korelasi atau hubungan antara kinerja karyawan (variabel dependen) dengan disiplin kerja dan kompensasi (variabel independen) mempunyai tingkat hubungan yang sangat kuat.
5. Koefisien Determinasi $\left(\mathrm{R}^{2}\right)$

Uji koefisien determinasi digunakan untuk mengetahui sebesar mana hubungan antara disiplin kerja (X1) dan kompensasi (X2) terhadap kinerja karyawan. hasil analisis uji koefisien determinasi dapat dilihat pada tabel berikut :

Tabel 6. Hasil Uji Koefisien Determinasi

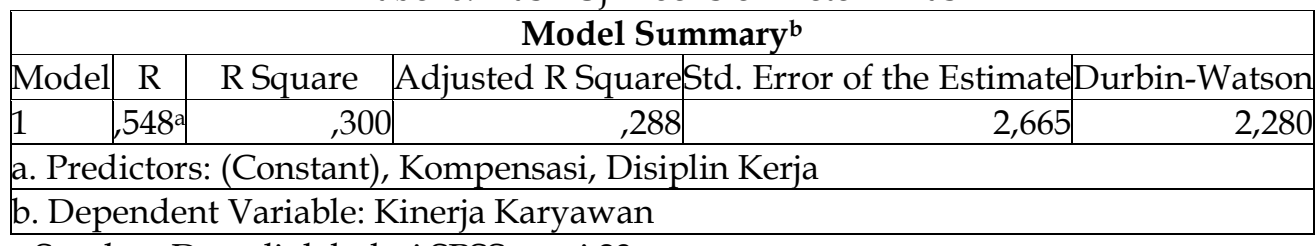

Sumber: Data diolah dari SPSS versi 23

Berdasarkan tabel di atas dapat diketahui bahwa besarnya $\mathrm{R}$ square adalah 0,300 atau $30 \%$. Hal ini menunjukan bahwa persentase pengaruh variabel independen disiplin kerja dan kompensasi (X) terhadap variabel dependen kinerja karyawan sebesar $30 \%$. Sedangkan sisanya $(100 \%$ $30 \%=70 \%$ ) dipengaruhi atau dijelaskan oleh variabel lain diluar variabel yang diteliti.

6. Uji Hipotesis

a. Uji Parsial (Uji t)

Uji statistik (uji t) bertujuan untuk menunjukan seberapa jauh pengaruh satu variabel independen secara individual dalam menerangkan variasi variabel dependen atau untuk menguji variabel bebas secara parsial (individu). Tabel $(\mathrm{t})$ dapat dilihat dari $\mathrm{t}(\mathrm{a} / 2: \mathrm{n}-\mathrm{k})=\mathrm{t}(0,025: 118)=1,98$

Tabel 7. Hasil Uji Parsial (T)

\begin{tabular}{|l|r|r|r|r|}
\hline \multicolumn{6}{|c|}{ Coefficients $^{\mathbf{a}}$} \\
\hline \multirow{2}{*}{ Model } & Unstandardized Coefficients Standardized Coefficients & \multirow{2}{*}{$\mathrm{t}$} & Sig. \\
\cline { 2 - 5 } & \multicolumn{1}{|c|}{ B } & Std. Error & & \\
\hline
\end{tabular}

Sumber: Data diolah dari SPSS versi 23

Berdasarkan tabel di atas, maka dapat diambil kesimpulan sebagai berikut:

1. Variabel disiplin kerja (X1) Variabel disiplin kerja 
mempunyai tingkat signifikansi sebesar 0,003 nilai ini lebih kecil dari $0,05(0,003<0,05)$ dengan nilai t hitung 3,031 > 1,980. Hal ini berarti $\mathrm{H} 0$ ditolak. Sehingga dapat dikatakan bahwa disiplin kerja berpengaruh signifikan terhadap kinerja karyawan

2. Variabel Kompensasi (X2)

$$
\text { Variabel kompensasi }
$$

mempunya tingkat signifikansi sebesar 0,001 nilai ini lebih kecil dari $0,05(0,001<0,05)$ dengan niilai t hitung $3,551>1,980$, hal ini berarti $\mathrm{H} 0$ ditolak. Sehingga dapat dikatakan bahwa kompensasi berpengaruh signifikan terhadap kinerja karyawan.

b. Uji Simultan (Uji F)

Uji statistic (F) bertujuan untuk menunjukan apakah semua variabel bebas atau independen yang dimasukkan dalam model regresi mempunyai pengaruh yang signifikan secara bersama-sama terhadap variabel dependen. Membandingkan $\mathrm{F}$ hitung dengan $\mathrm{F}$ tabel, dengan $\mathrm{F}$ tabel $=\mathrm{F}(\mathrm{k}: \mathrm{n}-\mathrm{k}-1)=\mathrm{F}$ $(2: 117)=3,07$. Apabila uji $\mathrm{F}$ dengan signifikansi kurang dari $0,05(<0,05)$ maka dapat disimpulkan bahwa variabel independen secara bersamasama berpengaruh signifikan terhadap variabel dependen.

Tabel 8. Hasil Uji Simultan (F)

\begin{tabular}{|l|l|r|r|r|r|c|}
\hline \multicolumn{7}{|c|}{ ANOVA $^{\text {Ma }}$} \\
\hline \multirow{4}{*}{1} & Sum of Squares & df & Mean Square & F & Sig. \\
\hline & Regression & 356,765 & 2 & 178,382 & 25,114 & $0^{0}$ \\
\cline { 2 - 7 } & Residual & 831,027 & 117 & 7,103 & & \\
\cline { 2 - 7 } & Total & 1187,792 & 119 & & & \\
\hline
\end{tabular}

Sumber: Data diolah dari SPSS versi 23

Dari tabel di atas, dapat diketahui bahwa nilai $\mathrm{F}$ hitung sebesar 25,114 sedangkan $F$ tabel sebesar 3,07, maka 25,114 > 3,07 dan secara statistic diperoleh nilai signifikansi sebesar $0,000<0,050$. Maka dari data tersebut dapat diartikan bahwa H0 ditolak. Hal ini menunjukan bahwa disiplin kerja dan kompensasi secara simultan mempunyai pegaruh yang signifikan terhadap kinerja karyawan.

\section{PEMBAHASAN HASIL PENELITIAN}

1. Disiplin kerja berpengaruh secara signifikan terhadap kinerja karyawan

Hasil pengujian hipotesis, terbukti bahwa disiplin kerja berpengaruh secara signifikan terhadap kinerja karyawan berdasarkan penelitian. Dimana dalam uji $t$ didapatkan hasil nilai $t$ hitung disiplin kerja sebesar 3,031 lebih besar jika dibandingakan dengan nilai $t$ tabel sebesar 1,980. Selain hal tersebut, dalam uji t juga diperoleh hasil signifikansi a untuk variabel disiplin kerja adalah 0,003 lebih kecil jika dibandingkan dengan dengan nilai alpha sebesar 0,05. Berdasarkan hasil pengujian yang diperoleh makan menolah $\mathrm{HO}$ dan menerima $\mathrm{H} 1$, artinya adalah secara parsial variabel disiplin kerja berpengaruh signifikan terhadap kinerja karyawan Rubber Process di PT. Pratama Abadi Industri Tangerang Selatan. Dengan demikian hasil pengujian hipotesa yang dilakukan mendukung penelitian sebelumnya mengenai pengaruh disipln kerja terhadap kinerja karyawan yaitu Nani Wibowo (2017)

2. Kompensasi berpengaruh secara signifikan terhadap kinerja karyawan

Hasil pengujian hipotesis, terbukti bahwa Kompensasi berpengaruh secara signifikan terhadap kinerja karyawan berdasarkan penelitian. Dimana dalam uji $\mathrm{t}$ didapatkan hasil nilai $\mathrm{t}$ hitung disiplin kerja sebesar 3,551 lebih besar jika dibandingakan dengan nilai $t$ tabel sebesar 1,980. Selain hal tersebut, dalam 
uji t juga diperoleh hassil signifikansi a untuk variabel disiplin kerja adalah 0,001 lebih kecil jika dibandingkan dengan dengan nilai alpha sebesar 0,05. Berdasarkan hasil pengujian yang diperoleh makan menolah $\mathrm{HO}$ dan menerima H1, artinya adalah secara parsial variabel disiplin kerja berpengaruh signifikan terhadap kinerja karyawan Rubber Process di PT. Pratama Abadi Industri Tangerang Selatan. Dengan demikian hasil pengujian hipotesa yang dilakukan mendukung penelitian sebelumnya mengenai pengaruh disipln kerja terhadap kinerja karyawan yaitu Bimpi Arispa Desenja (2018)

3. Disiplin kerja dan kompensasi secara simultan berpengaruh signifikan terhadap kinerja karyawan

Hasil pengujian hipotesis, terbukti bahwa disiplin kerja dan kompensasi secara simultan berpengaruh signifikan terhadap kinerja karyawan berdasarkan penelitian. Dimana dalam uji $F$ didapatkan hasil nilai $\mathrm{F}$ hitung disiplin kerja dan kompensasi secara simultan sebesar 25,114 lebih besar jika dibandingakan dengan nilai $\mathrm{F}$ tabel sebesar 3,07. Selain hal tersebut, dalam uji $F$ juga diperoleh hasil signifikansi a untuk variabel disiplin kerja dan kompensasi secara simultan sebesar adalah 0,000 lebih kecil jika dibandingkan dengan dengan nilai alpha sebesar 0,05. Berdasarkan hasil pengujian yang diperoleh makan menolak $\mathrm{H} 0$ dan menerima $\mathrm{H} 1$, artinya adalah secara simultan variabel disiplin kerja dan kompensasi berpengaruh signifikan terhadap kinerja karyawan Rubber Process di PT. Pratama Abadi Industri Tangerang Selatan. Dengan demikian hasil pengujian hipotesa yang dilakukan mendukung penelitian sebelumnya mengenai pengaruh disipln kerja terhadap kinerja karyawan yaitu $\mathrm{Al}$ Wariooy (2017)

\section{PENUTUP}

\section{Kesimpulan}

Berdasarkan hasil penelitian dan pembahasan mengenai Pengaruh Disiplin Kerja dan Kompensasi Terhadap Kinerja Karyawan Rubber Process pada PT. Tabad Industri Kota Tangerang Selatan yang telah diuraikan secara statistik dengan menggunakan program SPSS versi 23, maka penelitian ini dapat disimpulkan sebagai berikut :

a. Disiplin Kerja berpengaruh signifikan terhadap Kinerja Karyawan ditunjukan dengan tingkat signifikansi sebesar 0,003 nilai ini lebih kecil dari 0,05 $(0,003<0,05)$ dengan nilai $t$ hitung sebesar 3,031 nilai lebih besar dari $t$ tabel sebesar $1,98827(3,031>1,98827)$. Maka dapat dikatakan bahwa $\mathrm{H}_{0}$ ditolak, $\mathrm{H}_{1}$ diterima. Sehingga disiplin kerja mempunyai pengaruh yang signifikan terhadap kinerja karyawan.

b. Kompensasi berpengaruh signifikan terhadap Kinerja Karyawan ditunjukan dengan tingkat signifikansi sebesar 0,001 nilai ini lebih kecil dari 0,05 $(0,001<0,05)$ dengan niilai $t$ hitung 3,551 nilai ini lebih besar dari $t$ tabel sebesar 1,98827 $(3,551>1,98827)$. Maka dapat dikatakan bahwa $\mathrm{H}_{0}$ ditolak, $\mathrm{H}_{2}$ diterima. Sehingga kompensasi mempunyai pengaruh yang signifikan terhadap kinerja karyawan.

c. Disiplin Kerja dan Kompensasi secara simultan berpengaruh signifikan terhadap Kinerja Karyawan. Ditunjukan dengan nilai signifikansi sebesar 0,000 nilai ini lebih kecil dari $0,05(0,000<0,050$ dengan nilai $F$ hitung sebesar 25,114 lebih besar dari F tabel sebesar 3,11 $(25,114>3,11)$ Maka dari data tersebut dapat diartikan bahwa $\mathrm{H}_{0}$ ditolak, $\mathrm{H}_{3}$ diterima. Hal ini menunjukkan bahwa disiplin kerja dan kompensasi secara simultan mempunyai pegaruh yang signifikan terhadap kinerja karyawan. Pada uji analisis regresi berganda di peroleh suatu persamaan regresi 
yaitu $\mathbf{Y}=7,681+0,351 \mathrm{X} 1+\mathbf{0 , 4 0 1} \mathbf{X} \mathbf{2}$.

Nilai konstanta sebesar 7,681 , nilai koefisien disiplin kerja sebesar 0,351 dan nilai koefisien kompensasi sebesar 0,401. Pada uji Koefisien Determinasi (KD) diketahui bahwa $\mathrm{R}$ square adalah $30 \%$. Hal ini menunjukkan bahwa persentase pengaruh disiplin kerja (X1) dan kompensasi (X2) terhadap kinerja karyawan (Y) sebesar 30\%, sedangkan $70 \%$ dipengaruhi atau dijelaskan oleh variabel lain di luar variabel yang di teliti.

\section{Saran}

Hasil penelitian menyatakan bahwa disiplin kerja dan kompensasi sangat penting untuk menekankan semangat kerja para karyawan. Berdasarkan kesimpulan yang telah peneliti uraikan, maka ada beberapa saran yang perlu disampaikan, yaitu :

Disiplin Kerja memiliki pernyataan yang paling lemah yaitu pada indikator sanksi hukuman, untuk itu diharapkan para karyawan PT. Tabad Industri Kota Tangerang Selatan harus lebih meningkatkan kesadaran dan komitmen terhadap sanksi hukuman agar lahir rasa menghargai aturan yang telah di buat dalam keseharian di lingkungan kerja

\section{DAFTAR PUSTAKA}

Adi, Ahmad Eko, ISSN : 2622-8882, Vol. 3, No.4.Pengaruh Kompensasi Terhadap Kinerja Karyawan pada PT. berdikari Manunggal Perkasa di Serang Banten, Juli 2021

Badriyah, M. 2015. Manajemen Sumber Daya Manusia, (Cetakan 1). Bandung : CV Pustaka Setia.

Fahmi, Irham. 2017. Manajemen Sumber Daya Manusia. Bandung : Alfabeta.

Ghozali, Imam. 2012. Aplikasi Analisis Multivariate dengan Program IBM SPSS. Yogyakarta: Universitas Diponegoro

Handoko, T. Hani. 2014. Manajemen Personalia dan Sumber Daya Manusia. Yogyakarta : BPFE.
Harlan, Johan. 2018. Analisis Regresi Linier, (Cetakan Pertama). Depok : Gunadarma

Hasibuan, S.P, Malayu. 2018. Manajemen Sumber Daya Manusia, edisi revisi, Jakarta : Bumi Aksara.

Isvandiari, Any, ISSN : 0126-1258, Vol.11, No.2. Pengaruh Kompensasi dan Disiplin Kerja Terhadap Kinerja Karyawan Bagian Produksi PG. Meritjan Kediri, Juni 2017

Kasmir. 2016. Manajemen Sumber Daya Manusia ( Teori dan Praktik ). Depok : Rajagrafindo Persada.

Kirana, Kusuma Candra, Abraham Sukma Pradipta, ISSN : 2581-2769, Vol. 4, No. 3, Pengaruh Kepemimpinan, Kompensasi dan Motvasi Kerja Terhadap Kinerja Karyawan PT. JAK, Mei 2021

Kosasih, K., et al. (2020). The Effect of Compensation and Service Period on Employee Performance at PT. Infomedia Nusantara Branch Bandung. Kontigensi: Jurnal Ilmiah Manajemen, 8(2), 147-154.

L. Mathis, Robert danH. Jackson, John. 2011. Human Resource Management (edisi 10). Jakarta : Salemba Empat.

Mangkunegara, A.A, Anwar Prabu. 2013 Manajemen Sumber Daya Manusia Perusahaan. Bandung: Remaja Rosda karya.

Marlinah, Heni, Hendri Gunawan, ISSN : 2615-6849, Vol. 4, No.2, Pengaruh Disiplin Kerja dan Motivasi Kerja Terhadap Kinerja Pegawai Dinas Pendidikan dan Kebudayaan Kota Tangerang Selatan, Juni 2021

Muliawan, Fajar, ISSN : 2622-8882, Vol. 3, No. 4, Pengaruh Disiplin Kerja Terhadap Kinerja Karyawan Pada PT. Bank Mandiri, TBK. Kantor Cabang Kota Serang Banten, Juli 2021

Nawawi. 2011. Manajemen Sumber Daya Manusi Untuk Bisnis Yang Kompetitif, Yogyakarta : Gajahmada University Press.

Nurjaya, N., et al. (2021). Pengaruh Kompetensi Sumber Daya Manusia Dan Kemampuan Pemanfaatan 
Teknologi Terhadap Kinerja Aparatur Desa Pada Kantor Kepala Desa Di Kabupaten Gunungkidul, Yogyakarta. JENIUS (Jurnal Ilmiah Manajemen Sumber Daya Manusia), 4(3), 332-346.

Riduwan. 2015. Metode dan Teknik Menyusun Proposal Penelitian. (Cetakan ke- 6). Bandung: Alfabeta.

Saraswati, Ni Putu Ayu Sintya, Anak Agung Dwi Widyani, Ayu Stevi Rani, ISSN : 2581-2769, Vol.4, No. 3, Pengaruh Disiplin kerja dan kecerdasan Emosional terhadap kinerja karyawan di Mediasi oleh Kepuasan Kerja Karyawan Pada PT. Angkasa Pura Support Bali di Kabupaten Badung, Mei 2021

Sartika, Dewi, Riski Dwi Nugroho, Inama Elliska, ISSN : 2615-6849, Vol. 4, No. 2, Pengaruh Motivasi Kerja dan Kompensasi Terhadap Kinerja Karyawan Pada PT. Laris Indo Sukses Gemilang Tangerang Selatan, Juni 2021.

Seta, A. B., et al. (2021). Pengaruh Pelatihan Dan Kompensasi Terhadap Prestasi Kerja Yang Berdampak Pada Kinerja Karyawan Pada PT Cipta Mega
Sarana Di Jakarta. Jurnal Ekonomi Efektif, 4(1), 148-159.

Sugiyono. 2016. Metode Penelitian Manajemen. (Cetakan ke-5). Bandung: Alfabeta.

Sumaeni, Endang, ISSN : 2598-9502, Vol. 4, No. 3, Pengaruh Kedisiplinan Dan Kompensasi Karyawan Terhadap Kinerja Karyawan Di Bank Muamalat Kc Surabaya - Mas Mansyur, Mei 2017.

Susanti, Fahmi, ISSN : 2598-9545, Vol.4, No. 3, Pengaruh disiplin kerja, Motivasi Kerja terhadap kinerja karyawan Glory Store Indonesia, Juli 2021

Sutrisno, Edi. 2016. Manajemen Sumber Daya Manusia. Jakarta : Kencana Prenada Media Group.

Sutrisno, Edi. 2020. Manajemen Sumber Daya Manusia, (Cetakan ke-11). Jakarta : Kencana.

Sutrisno, Yanurianto, Yossy Wahyu Indrawan, ISSN : 2622-8882, Vol. 3, No. 4, Pengaruh Pelatihan dan Disiplin Kerja Terhadap Kinerja Karyawan pada PT. Pratama Abadi Industri di Tangerang, Juli 2021

Wibowo. 2016. Manajemen Kinerja, (Edisi Kelima). Jakarta : PT.Rajagrafindo Persada. 